\title{
Population genetic structure of an estuarine and a reef fish species exploited by Brazilian artisanal fishing
}

\author{
Regina H.G. Priolli ${ }^{1,4}$, Miklos M. Bajay ${ }^{2}$, Renato A.M. Silvano ${ }^{1,3}$, Alpina Begossi ${ }^{1,4}$ \\ ${ }^{1}$ Fisheries and Food Institute - FIFO, PPG Ecomar, UNISANTA, R. Cesário Mota 08, CEP: 11045-040, Santos, SP, Brazil. \\ E-mail: rhpriolli@gmail.com \\ ${ }^{2}$ Department of Genetics, ESALQ, USP, Av. Pádua Dias 11, CEP: 13400-970, Piracicaba, SP, Brazil. \\ ${ }^{3}$ Department of Ecology, UFRGS, CP 15007, CEP: 91501-970, Porto Alegre, RS, Brazil. \\ ${ }^{4}$ Nepa, Capesca, UNICAMP, Av. Albert Einstein 291, CEP: 13083-852, Campinas, SP, Brazil.
}

\begin{abstract}
Summary: In this study, we used microsatellite markers to examine the genetic structures of Centropomus undecimalis (Bloch, 1792) and Epinephelus marginatus (Lowe, 1834) populations collected from artisanal fishing sites along a stretch of coastline in southeastern Brazil. Based on F-statistics, there was no significant genetic differentiation evident in any $C$. undecimalis samples $\left(\mathrm{F}_{\mathrm{ST}}=0.012\right)$. However, Bayesian clustering, principal component analysis $(\mathrm{PCA})$ and discriminant analysis of principal components (DAPC) results suggested that there were most likely two clusters, with no relation to geographic areas. The bottleneck results showed no significant values and the effective population sizes $\left(\mathrm{N}_{\mathrm{e}}\right)$ for the two genetically differentiated groups were large and similar. In contrast, for E. marginatus populations, the microsatellite loci showed no population subdivisions. The $\mathrm{F}_{\mathrm{ST}}$ value was low and non-significant $\left(\mathrm{F}_{\mathrm{ST}}=0.008\right)$, a Bayesian analysis indicated one cluster, and a PCA showed that all samples from different geographical sites shared the same genetic structure. The bottleneck results exhibited significant differences, and a low $\mathrm{N}_{\mathrm{e}}$ was observed. The results of the genetic study of these two species along the southeastern Brazilian coast suggest that the distinct genetic structure of each species should be taken into account as management units for the conservation of their genetic diversities.
\end{abstract}

Keywords: small-scale fisheries; microsatellites; genetic diversity; common snook; dusky grouper; bottleneck.

Estructura genética poblacional de dos especies piscícolas, una de estuario y una de arrecife, explotados por la pesca artesanal brasilera

Resumen: En este estudio se han utilizado marcadores microsatélites para examinar la estructura genética de Centropomus undecimalis (Bloch, 1792) y Epinephelus marginatus (Lowe, 1834) en localidades de pesca artesanal localizadas a lo largo de la costa del sudeste de Brasil. Los estadísticos de diferenciación poblacional (F-statisctics) no presentaron diferenciación genética entre las muestras de $C$. undecimalis $\left(\mathrm{F}_{\mathrm{ST}}=0.012\right)$. Sin embargo, los resultados de los análisis basados en clústeres bayesianos, componentes principales (PCA) y análisis discriminante de componentes principales (DAPC) sugieren la posible presencia de dos clústeres diferenciados genéticamente, pero sin ninguna relación con las áreas geográficas. Los resultados del análisis de cuello de botella poblacional no son significativos con valores de tamaño efectivo poblacional $\left(\mathrm{N}_{\mathrm{e}}\right)$ elevados y similares entre los dos clústeres. Por el contrario, en E. marginatus, los análisis basados en microsatélites no muestran ningún patrón de subdivisión genética. El valor de $\mathrm{F}_{\mathrm{ST}}$ es bajo y no significativo $\left(\mathrm{F}_{\mathrm{ST}}=0.008\right)$, el análisis Bayesiano indicia un solo clúster y el PCA determina que todas las muestras de las diferentes localidades geográficas comparten la misma estructura genética. El análisis de cuello de botella muestra diferencias significativas con la observación de una baja $\mathrm{N}_{\mathrm{e}}$. Los resultados de los análisis genéticos en estas dos especies a lo largo de la costa sudeste de Brasil sugieren diferentes estructuras genéticas para cada especie y estos resultados deben tenerse en consideración para la estipulación de las medidas de conservación de la diversidad genética.

Palabras clave: pesquerías a pequeña escala; microsatélites; diversidad genética; róbalo; mero; cuello de botella.

Citation/Como citar este artículo: Priolli R.H.G., Bajay M.M., Silvano R.A.M., Begossi A. 2016. Population genetic structure of an estuarine and a reef fish species exploited by Brazilian artisanal fishing. Sci. Mar. 80(4): 000-000. doi: http:// dx.doi.org/10.3989/scimar.04407.17A

Editor: J. Viñas.

Received: January 27, 2016. Accepted: September 27, 2016. Published: October 20, 2016.

Copyright: () 2016 CSIC. This is an open-access article distributed under the terms of the Creative Commons Attribution (CC-by) Spain 3.0 License. 


\section{INTRODUCTION}

A recent report on snappers and groupers (Amorim and Westmeyer 2016) shows that information on stocks is unclear, especially in developing countries that do not have a reporting system based on catch and effort data. This is particularly the case in Brazil, where there is no systematic data collection on the stocks of snook (Centropomus spp.) and groupers (Epinephelus spp.). To address this lack, we present here new data on the genetic diversities of Centropomus undecimalis (Bloch, 1792) and Epinephelus marginatus (Lowe, 1834) from fishing spots off the southeastern coast of Brazil.

These two biologically different species are among the most exploited fish in two ecologically relevant habitats (estuaries and reefs) in the western Atlantic. The common snook, $C$. undecimalis, is a protandric hermaphrodite and a diadromous, euryhaline and estuarine fish. The development of this fish includes an inshore larval stage, with juveniles colonizing estuarine environments, including mangroves, drainage areas, sea grass beds and shallow waters (Taylor et al. 2000). Interviews with local fishermen indicate that this fish spawns in summer and spring (Begossi et al. 2012a). Its capture is associated with migratory movements to freshwater ecosystems (Silvano et al. 2006), and its capture is also linked to spawning events in the coastal zone (Able 2005). These situations can promote decreases in fishery resources, with potential detrimental effects on population size (Perera et al. 2011).

Nuclear markers such as microsatellites or simple sequence repeats (SSRs) have been used to study genetic differences among populations, and these studies have confirmed the hypothesis that restricted gene flow between common snook originated from the Atlantic and Gulf of Mexico off the coast of Florida (Seyoum et al. 2005, Tringali et al. 2008). Studies of microsatellite loci also found that snook from contrasting environments, marine and freshwater, belong to the same genetic stock (Hernandez-Vidal et al. 2014).

The dusky grouper, E. marginatus, is a reef fish that inhabits rocky bottoms, from shallow waters to depths of more than 200 metres, and lives in caves (Andrade et al. 2003). It is a monandric, protogynous hermaphrodite, is sedentary and shows slow growth. It has been reclassified as a protected species in the Mediterranean (Bouchereau et al. 1999) and has been listed as endangered by the International Union for the Conservation of Nature (IUCN) since 1996. Large predators, including E. marginatus, have important ecological functions in reef ecosystems (Mumby et al. 2011). These fish species can also be good indicators of the effectiveness of biological conservation efforts, such as those that occur in marine protected areas (Anderson et al. 2014).

Studies of E. marginatus populations have been carried out using selected microsatellite markers developed for Mycteroperca microlepis (Chapman et al. 1999), Epinephelus quernus (Rivera et al. 2003) and Epinephelus guttatus (Ramirez et al. 2006). Genetic differentiation between the populations from the Atlantic and Mediterranean waters, as well as those within the Mediterranean (De Innocentiis et al. 2001, Schunter et al. 2011), has been observed. In a previous work on the genetic diversity of $E$. marginatus populations in Paraty (Rio de Janeiro, Brazil), the same microsatellite markers showed high diversity (Priolli et al. 2014).

Small-scale fisheries frequently exploit environments that have a high degree of aquatic and fish biodiversity, and these fisheries involve fishing for consumption and sale (McClanahan et al. 2006, Begossi et al. 2012a). However, there is evidence that even artisanal fishing can impact target fish populations (Pinnegar and Engelhard 2008). Artisanal fisheries account for about $50 \%$ of the overall Brazilian fish catch, but there is a scarcity of basic data on these catches, which is an obstacle for making temporal comparisons (Begossi et al 2012a). Also, there is often no information available about the status of vulnerable species that are commercially important (Begossi et al. 2012b).

In this study, we used microsatellite markers to examine the genetic structure of the $C$. undecimalis and E. marginatus populations along a stretch of the southeastern Brazilian coastline. Information about the genetic diversities and population structures of these species can eventually be translated into management and conservation strategies. Our goals were to (1) test the alternative hypotheses of panmixia versus genetic population subdivisions for each species, (2) assess the genetic diversity, bottleneck and effective population size of each species, and (3) provide insights for the conservation of these species that takes their genetic diversities into account.

\section{MATERIALS AND METHODS}

\section{Sample collection and DNA extraction}

Samples from the two species (one sample per individual fish) were collected from the artisanal fishery landing points in Paraty (Rio de Janeiro State, Brazil). At this specific site only, during two weeks per month, fishermen were approached as soon as they arrived at one of two main landing points (Fig. 1). They were asked for their permission to weigh and measure their catch, which was then identified using local names. A questionnaire was used to determine the main fishing spots and target species and to confirm fish identifications (Begossi et al. 2012b, Lopes et al. 2013). We collected 76 and 122 individual $C$. undecimalis and $E$. marginatus, respectively, at two landing points for the Paraty fishery (Table 1).

To increase the sampling area, we collected 15 additional samples of $C$. undecimalis from artisanal fisheries from one landing point in Ubatuba (São Paulo State) and 30 additional samples of E. marginatus from one landing point in Rio de Janeiro (Rio de Janeiro State). In these cases, the fish collected from fishermen's catches were mostly bought from the fishers at the landing points, which are also local fish markets. Only Ubatuba catches were weighed and measured.

Samples of muscle or the caudal fin (approximately $2 \mathrm{~cm}^{2}$ ) of each individual were stored in $70 \%$ ethanol 


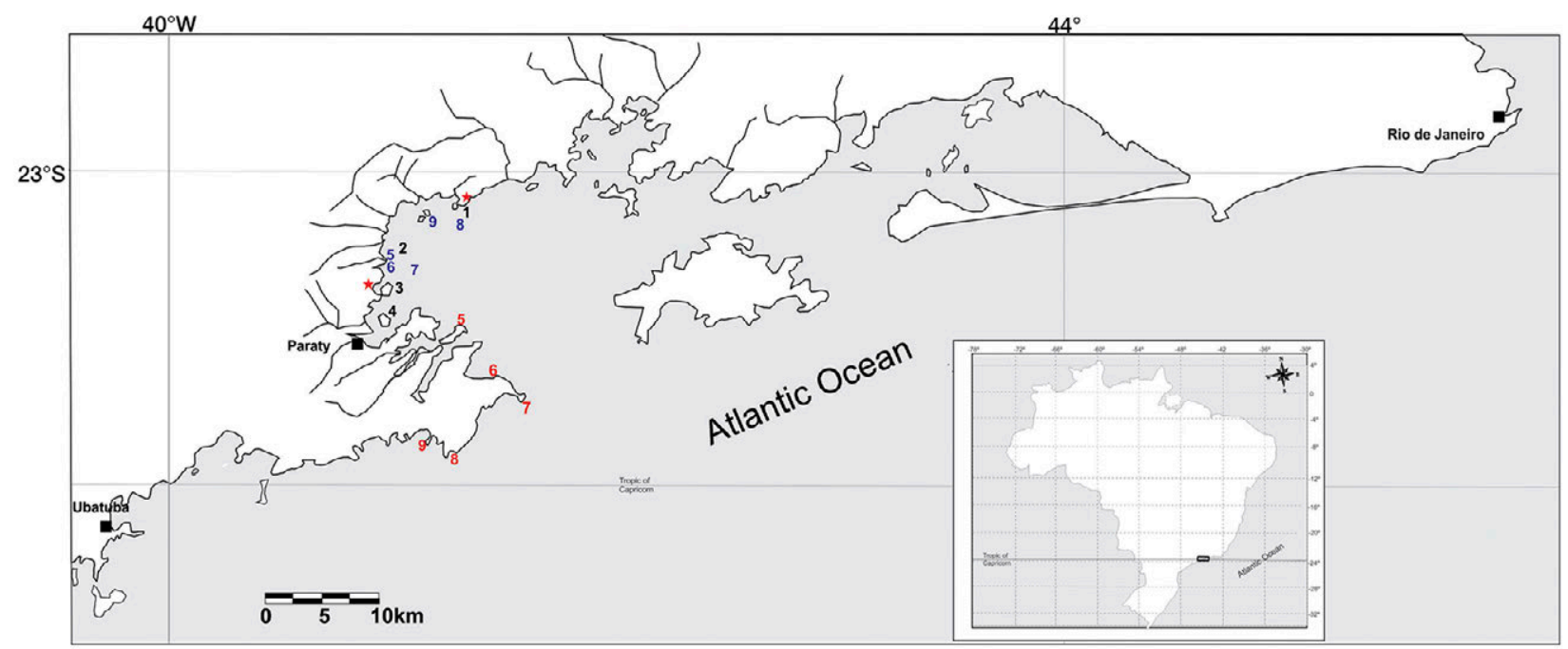

Fig. 1. - Map of Paraty artisanal fishing sites on the coast of the states of Rio de Janeiro and São Paulo, Brazil. Red stars indicate landing ports. The fishing spots that were used by the communities of Paraty to catch $C$. undecimalis (blue or black numerals: 1 , Tarituba; 2, Ilha do Pico; 3 , Ilha do Araújo; 4, Baía de Paraty; 5, Canto do Morro; 6, Ilha do Ventura; 7, Ilha Rasa; 8, Aracaíba; 9, Laje Sete Cabeças) and E. marginatus (red or black numerals: 1, Tarituba; 2, Ilha do Pico; 3, Ilha do Araújo; 4, Baía de Paraty; 5, Ilha do Algodão; 6, Cajaíba; 7, Joatinga; 8, Ponta Negra; 9, Sono).

Table 1. - Details of the Centropomus undecimalis and Epinephelus marginatus sampling sites, with the number of individuals (N) and their average length and weight. (-) indicates no data collected.

\begin{tabular}{|c|c|c|c|c|c|c|}
\hline Species & Sites & Coordinates & $\mathrm{N}$ & Date & Length (cm) & Weight $(\mathrm{g})$ \\
\hline C. undecimalis & $\begin{array}{l}\text { Paraty } \\
\text { Ubatuba }\end{array}$ & $\begin{array}{l}23^{\circ} 13^{\prime} 04^{\prime \prime} \mathrm{S}, 44^{\circ} 42^{\prime} 47^{\prime \prime} \mathrm{W} \\
23^{\circ} 26^{\prime} 02^{\prime \prime} \mathrm{S}, 45^{\circ} 04^{\prime} 16^{\prime \prime} \mathrm{W}\end{array}$ & $\begin{array}{l}76 \\
15\end{array}$ & $\begin{array}{l}\text { December 2009-April } 2011 \\
\text { December 2010-April } 2011\end{array}$ & $\begin{array}{c}70.96 \pm 12.889 \\
83.93 \pm 9.888\end{array}$ & $\begin{array}{l}3.48 \pm 1.585 \\
6.26 \pm 2.190\end{array}$ \\
\hline E. marginatus & $\begin{array}{l}\text { Paraty } \\
\text { Rio de Janeiro }\end{array}$ & $\begin{array}{l}23^{\circ} 13^{\prime} 04^{\prime \prime} \mathrm{S}, 44^{\circ} 42^{\prime} 47^{\prime \prime} \mathrm{W} \\
22^{\circ} 54^{\prime} 10^{\prime \prime} \mathrm{S}, 43^{\circ} 12^{\prime} 27^{\prime \prime} \mathrm{W}\end{array}$ & $\begin{array}{l}122 \\
30\end{array}$ & $\begin{array}{l}\text { December 2009-April } 2011 \\
\text { December 2010-April } 2011\end{array}$ & $35.93 \pm 6.411$ & $\begin{array}{c}0.90 \pm 0.551 \\
-\end{array}$ \\
\hline
\end{tabular}

at $4{ }^{\circ} \mathrm{C}$, shipped on ice to the laboratory and lyophilized for two days under 0.040 mbar and at $-50^{\circ} \mathrm{C}$ (Alpha 1.2 LD Plus, Martin Christ, Osterode, Germany). DNA was isolated from a few milligrams of lyophilized tissue using a protocol developed by Shiozawa et al. (1992), with some modifications (Almeida et al. 2001). DNA quality and concentration were evaluated via electrophoresis in agarose gels following staining with SYBR Safe (Invitrogen, CA, USA).

\section{Microsatellite analyses}

Centropomus undecimalis: Fifteen microsatellite loci were amplified using primer pairs specifically described for C. undecimalis (Cun01, Cun03, Cun05B, Cun08, Cun09, Cun10A, Cun11, Cun12, Cun14, Cun16, Cun17, Cun18, Cun19, Cun22 and Cun23) (Seyoum et al. 2005). Polymerase chain reaction (PCR) assays were performed in a final volume of 20 $\mu \mathrm{L}$ containing $15 \mathrm{ng}$ DNA, $50 \mathrm{mM} \mathrm{KCl}, 10 \mathrm{mM}$ Tris$\mathrm{HCl}(\mathrm{pH} 8.9), 250 \mu \mathrm{M}$ of each dNTP, $0.2 \mu \mathrm{M}$ BSA, 2.0_mM $\mathrm{MgCl}_{2}, 0.16 \mu \mathrm{M}$ forward primer, $0.20 \mu \mathrm{M}$ reverse primer, $0.13 \mu \mathrm{M}$ M13 primer (IRDye 700 or IRDye 800, LI-COR Corporate, NE, USA) and 1.0 unit Taq DNA polymerase (Life Technologies, CA, USA). The reactions were amplified using a PTC-200 thermocycler (MJ Research, MA, USA) with the following 'touchdown' cycling programme: $95^{\circ} \mathrm{C}$ for $10 \mathrm{~min}$, followed by 7 cycles of $94^{\circ} \mathrm{C}$ for $1 \mathrm{~min}, 67^{\circ} \mathrm{C}$ decreasing to $53^{\circ} \mathrm{C}$ at $2^{\circ} \mathrm{C}$ per cycle for $1 \mathrm{~min}$, and $72^{\circ} \mathrm{C}$ for $1 \mathrm{~min}$, followed by 24 cycles of $94^{\circ} \mathrm{C}$ for $30 \mathrm{~s}, 53^{\circ} \mathrm{C}$ for $40 \mathrm{~s}$, and $72^{\circ} \mathrm{C}$ for $1 \mathrm{~min}$, and a final extension step at $72^{\circ} \mathrm{C}$ for $10 \mathrm{~min}$.

The products of the amplification were separated on a $6.5 \%(\mathrm{w} / \mathrm{v})$ polyacrylamide gel with a 4300 DNA Analyser (LI-COR Corporate). The data were collected automatically based on the differential fluorescence (700 or $800 \mathrm{~nm}$ ) of the products, and allele scoring was performed using the program SAGA MX Generation (LI-COR Corporate, NE, USA).

Epinephelus marginatus: Eight microsatellite loci were amplified from $5 \mathrm{ng}$ of extracted E. marginatus DNA using primer pairs originally developed for $M y$ cteroperca microlepis (GAG007, GAG008, GAG010, GAG023, GAG045 and GA049) (Chapman et al. 1999) and for Epinephelus quernus (CA-3 and CA-6) (Rivera et al. 2003). The DNA extraction and PCR conditions were the same as those for $C$. undecimalis, with the exceptions of the $\mathrm{MgCl}_{2}$ concentration, which was modified to $1.5 \mathrm{mM}$, and annealing temperature, which started at $54^{\circ} \mathrm{C}$ and then decreased to $40^{\circ} \mathrm{C}$.

\section{Data analysis}

Genotype and allele frequencies of the microsatellite loci from each species were analysed to obtain standard genetic diversity estimates.

The total number of alleles $\left(\mathrm{N}_{\mathrm{A}}\right)$, allelic richness $\left(\mathrm{A}_{\mathrm{R}}\right)$, observed heterozygosity $\left(\mathrm{H}_{\mathrm{O}}\right)$ and expected heterozygosity $\left(\mathrm{H}_{\mathrm{E}}\right)$ were calculated with FSTAT v. 2.9.3 (Goudet 1995). The departures from Hardy-Weinberg equilibrium (HWE) and the linkage disequilibrium 
between pairs of loci, with significance set at $\mathrm{P}<0.05$, were assessed with GENEPOP v. 4.1 (Raymond and Rousset 1995) and were later adjusted using a sequential Bonferroni correction (Rice 1989). Variations in allelic frequencies were quantified using F-statistics $(f, \mathrm{~F}, \theta)$ per locus over samples, which correspond to Wright's $\mathrm{F}_{\mathrm{IS}}, \mathrm{F}_{\mathrm{IT}}$ and $\mathrm{F}_{\mathrm{ST}}$, respectively. The statistical significance of departures from zero was tested using bootstrapping over loci (FSTAT). Null allelic frequencies were calculated based on the method of Brookfield (1996), using the program MICRO-CHECKER v. 2.2.3 (Van Oosterhout et al. 2004) and the expectation maximization algorithm (Dempster et al. 1977). The influence of null alleles was determined in FREENA (Chapuis and Estoup 2007) by computing the genetic divergence parameter $\mathrm{F}_{\mathrm{ST}}$ values using an ENA (excluding null alleles) correction. After accounting for null allele frequencies, loci with frequencies of $\geq 0.2$ were considered potentially problematic for the calculations.

The genetic structure based on the microsatellite data was further investigated using a Bayesian modelbased Markov Chain Monte Carlo clustering method and was implemented using the program STRUCTURE v. 2.3.3 (Pritchard et al. 2000, Hubisz et al. 2009). This method estimates the number of genetic clusters $(\mathrm{K})$ without any a priori assumptions about the population structure. The following parameters for each species were applied to the analysis: diploid, an admixture model and correlated allele frequencies. Following a burn-in period of 300000 , ten independent runs were performed for each $\mathrm{K}$ value (from 1 to $10)$, with 500000 iterations. The true value of $K(\Delta K)$ was chosen according to the method of Evanno et al. (2005) using STRUCTURE HARVESTER 0.6.7 (Earl and VonHoldt 2012). The graphs of the STRUCTURE results were produced using CLUMPP (Jakobsson and Rosenberg 2007). We used a Q matrix from the structure to assign individuals to different $\mathrm{Ks}$ (referred to here as 'clusters' for simplicity) using a critical level of $>50 \%$ for each one. Two AMOVAs were then performed in ARLEQUIN 3.11 (Excoffier et al. 2005) on $F_{\text {ST }}$ values (1,000 permutations) to quantify the levels of genetic differentiation among and within (1) the geographic groups and (2) the clusters previously identified with STRUCTURE. The same criteria were used for a principal components analysis (PCA) conducted in $\mathrm{R}$ ( $\mathrm{R}$ Development Core Team 2015) and using the APE (Paradis et al. 2004) and GGPLOT2 packages (Ginestet 2011).

To corroborate the outputs from the Bayesian analysis, we also analysed the datasets via a discriminant analysis of principal components (DAPC) (Jombart et al 2010) using the ADEGENET package (Jombart 2008) for R (R Development Core Team 2015). The number of clusters was assessed using the function find.clusters, which runs successive rounds of K-means clustering with an increasing number of clusters (K). To select the optimal number of clusters, we chose the lowest associated Bayesian information criterion (BIC) value.

The frequency distributions of the fish traits (weight and length) of each cluster identified by STRUCTURE and the DAPC were compared using a two-sample Kol-
mogorov-Smirnov test (Snedecor and Cochran 1989). In each analysis (STRUCTURE and DAPC), the two clusters observed were compared based on individuals whose inferred ancestry values were greater than 0.50 .

The clusters formed using STRUCTURE were also investigated in relation to genetic bottleneck signatures in three mutational models: the Infinite-Alleles Model (IAM), the Stepwise-Mutation Model (SMM) and the Two-Phase Model (TPM, with a 90\% SMM and 10\% variance) using BOTTLENECK 1.2.02 software (Piry et al. 1999).

The effective population size $\left(\mathrm{N}_{\mathrm{e}}\right)$ was calculated for each management unit previously established in STRUCTURE using LDNe 1.31 software (Waples and Do 2008). To avoid biases due to sample size for cases in which more than one cluster was detected, we chose an equal and random subset of individuals (approximately 40 individuals) for each cluster.

Finally, to evaluate the statistical power of the microsatellite markers to detect genetic differentiation at various levels of $\mathrm{F}_{\mathrm{ST}}$, we used POWSIM v.4.0 software (Ryman and Palm 2006). Four levels of population differentiation $\left(\mathrm{F}_{\mathrm{ST}}=0.0025,0.005,0.01,0.025\right)$ were pre-defined with effective population sizes of $\mathrm{N}_{\mathrm{e}}=500$ and $\mathrm{N}_{\mathrm{e}}=1000$, varying the number of generations $(t)$ accordingly (Ryman et al. 2006). Power is expressed as the proportion of significant outcomes (1000 replicates, rejecting the null hypothesis Ho of no difference in allele frequency, or $\mathrm{F}_{\mathrm{ST}}=0$ at $\mathrm{P}<0.05$ ).

\section{RESULTS}

\section{Centropomus undecimalis}

All 15 microsatellite loci were polymorphic in $C$. undecimalis. The number of alleles per locus across all populations ranged from 3 (Cun19) to 15 (Cun22), with a mean of 8.333 and 6.267 for Paraty and Ubatuba, respectively. The allelic richness showed similar values between the two sites, with an average of $5.19 \pm 0.10$ alleles. Tests for genotypic linkage disequilibrium confirmed the null hypothesis of the independence of loci pairs $(\mathrm{P}<0.01)$. On average, the observed heterozygosity values for samples from Paraty and Ubatuba were 0.5612 and 0.5989 , respectively, which were lower than the expected heterozygosity values, i.e. 0.7118 and 0.7137 , respectively. After sequential Bonferroni corrections were applied, a total of eight loci showed significant deviations from HWE $(\mathrm{P}<0.05)$, with only one locus (Cun09) observed at both sites. In all cases, the presence of null alleles was demonstrated by the MICRO-CHECKER program as a possible cause of the excess homozygosity observed, but the results of the analyses for all loci using FREENA with and without ENA correction were very similar, i.e. 0.012 and 0.010 , respectively.

Genetic differentiation, quantified using F-statistics for all samples, was not significant $\left(\mathrm{F}_{\mathrm{ST}}=0.012\right.$, $\mathrm{P}>0.05)$. However, the results of the Bayesian clustering analysis (using STRUCTURE) and Evanno's method suggested that the most probable $\mathrm{K}$ value (number of clusters) was $\mathrm{K}=2$ (Fig. 2A), with 42 and 

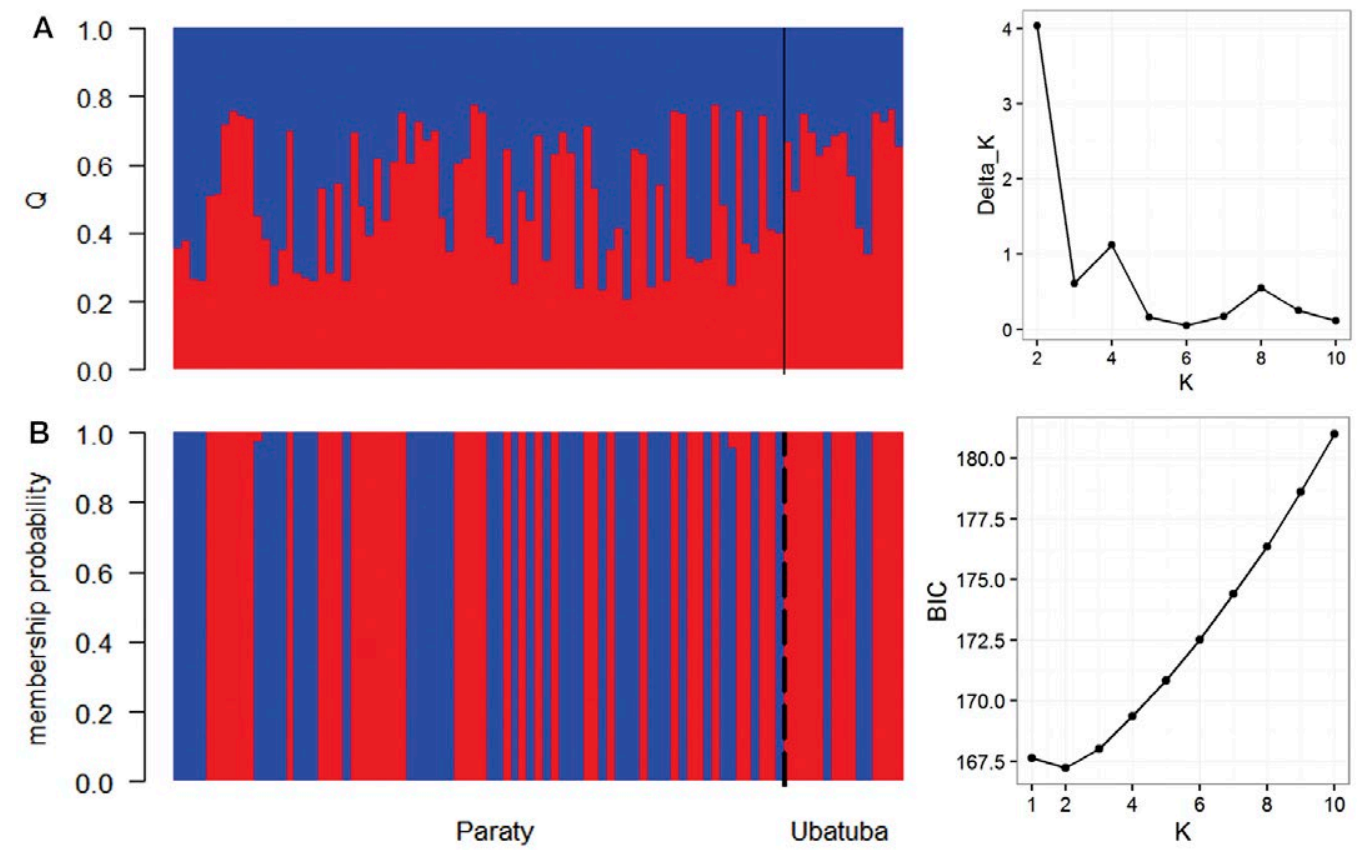

Fig. 2. - A, results of a Bayesian analysis (STRUCTURE) of samples of $C$. undecimalis and estimates of the number of K groups based on the Delta K statistic of Evanno et al. (2005); B, results of a DAPC analysis and the number of clusters as a function of the BIC values. Both results were based on the analysis of 91 individual $C$. undecimalis using 15 SSR loci from the Paraty (RJ) and Ubatuba (SP) regions, as indicated on the X-axis. Each column represents a different individual, and the colours represent the probability coefficient of each individual for each genetic cluster: Cluster 1 (red) and Cluster 2 (blue).

49 individuals predicted in each cluster, $\left(\mathrm{F}_{\mathrm{ST}}=0.040\right.$, $\mathrm{P}<0.05$ ). Notably, clusters 1 (blue) and 2 (red) are not defined in relation to the previous geographic groups (Paraty or Ubatuba). We also performed two AMOVAs to support the Bayesian genetic structure and detected a $0.09 \%$ variability, which was not significant, among the geographic groups $\left(\Phi_{\mathrm{ST}}=0.0009, \mathrm{P}>0.01\right)$ and a $4.45 \%$ variability, which was significant, among the clusters $\left(\Phi_{\mathrm{ST}}=0.045, \mathrm{P}<0.01\right)$.

A

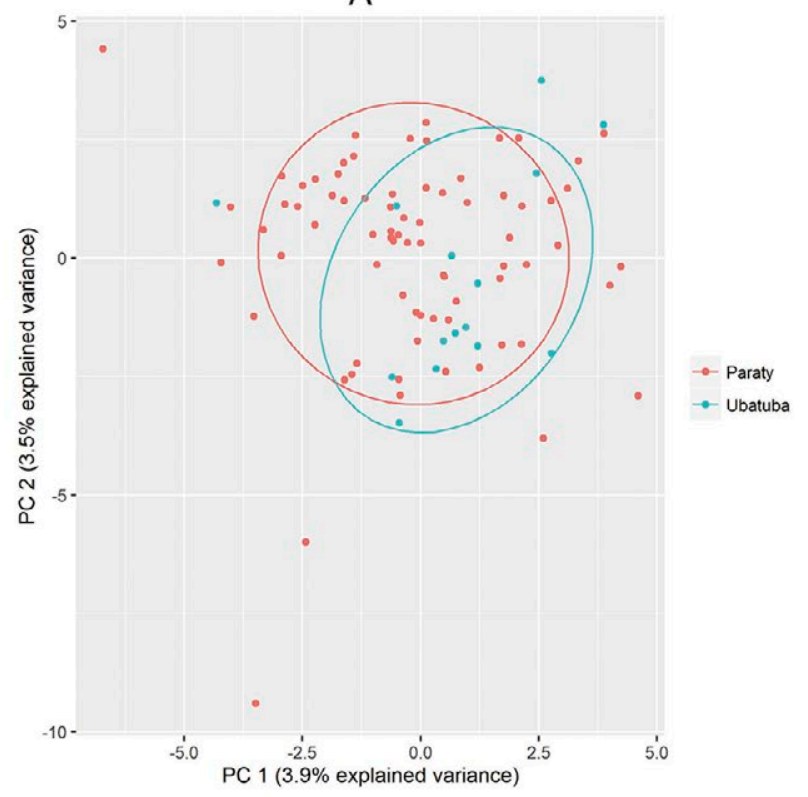

The presence of a hierarchical structure among the individual $C$. undecimalis was also observed using a method independent of the STRUCTURE analysis. According to the BIC, the optimal number of groups from the DAPC was $\mathrm{K}=2$ (Fig. 2B), with clusters containing 42 (Cluster 1 , blue) and 49 (Cluster 2, red) individuals. The inferred ancestry of $C$. undecimalis individuals, as shown along the main axes of the PCA in the DAPC, indicates a greater separation of clusters

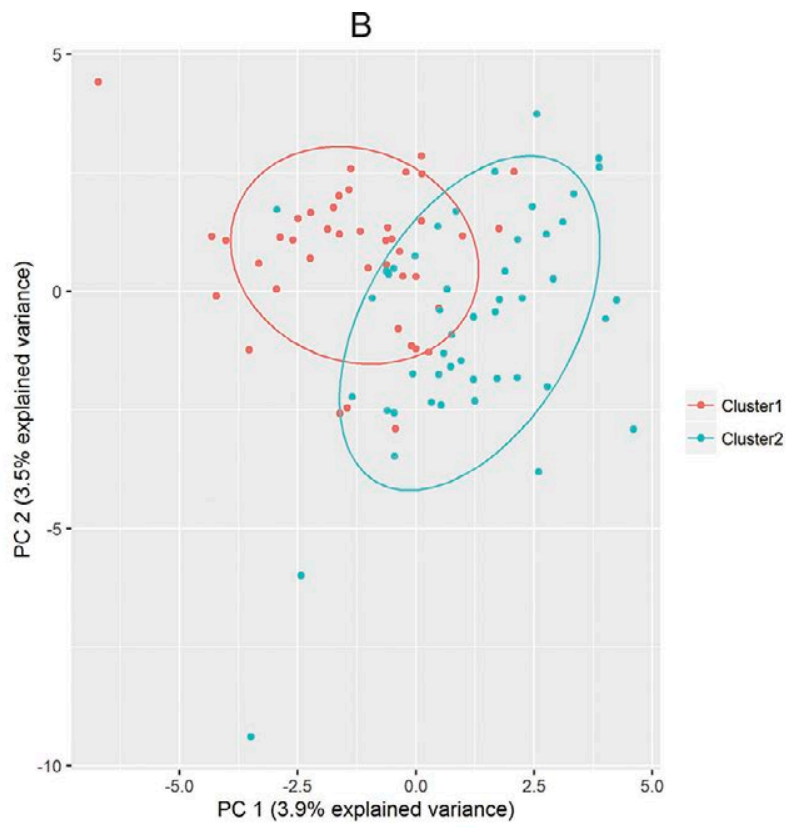

Fig. 3. - Dispersion plots of the first (PC1) and second (PC2) principal components based on the analysis of 91 individual $C$. undecimalis using 15 SSR loci. The ellipses, shown in different colours, represent the analysed individuals in two different analyses. A, populations divided into two groups according to geographical area: Paraty and Ubatuba coasts; B, populations divided into two groups according to the clusters identified using STRUCTURE. 
Table 2. - Results from the BOTTLENECK tests for 15 microsatellite loci studied in $C$. undecimalis divided into the two clusters (1 and 2) identified using STRUCTURE. Sign and Wilcoxon tests for excess heterozygosity: N, number of individuals analysed; Hde, number of loci showing a heterozygosity deficiency; Hex, number of loci showing excess heterozygosity. IAM, Infinite-Allele Model, TPM, Two-Phase Model (90\% SMM), SMM, Stepwise-Mutation Model, * significant values from the sign/Wilcoxon test $(\mathrm{P} \leq 0.05)$.

\begin{tabular}{|c|c|c|c|c|c|c|c|}
\hline Division & $\mathrm{N}$ & $\begin{array}{c}\text { IAM } \\
\text { Hde/Hex }\end{array}$ & $\begin{array}{c}\text { Sign/Wilcoxon test } \\
\text { P }\end{array}$ & $\begin{array}{c}\text { TPM } \\
\text { Hde/Hex }\end{array}$ & $\begin{array}{c}\text { Sign/Wilcoxon test } \\
\text { P }\end{array}$ & $\begin{array}{c}\text { SMM } \\
\text { Hde/Hex }\end{array}$ & $\begin{array}{c}\text { Sign/Wilcoxon test } \\
\text { P }\end{array}$ \\
\hline Cluster 1 & 42 & $5 / 10$ & $0.3742 / 0.2523$ & $11 / 4$ & $0.0103 * / 0.0730$ & $11 / 4$ & $0.0108 * / 0.0083^{*}$ \\
\hline Cluster 2 & 49 & $6 / 9$ & $0.5957 / 0.6787$ & $10 / 5$ & $0.0398 * / 0.0353 *$ & $12 / 3$ & $0.0023 * / 0.0083^{*}$ \\
\hline
\end{tabular}

Table 3. - Results from the POWSIM tests for 15 microsatellite loci studied in $C$. undecimalis divided into the two clusters (1 and 2) identified using STRUCTURE. Four levels of population differentiation $\left(\mathrm{F}_{\mathrm{ST}}=0.0025,0.005,0.01,0.025\right)$ were pre-defined with populations sizes $\mathrm{N}_{\mathrm{e}}=500$ and $\mathrm{N}_{\mathrm{e}}=1000$, and the simulation was replicated 1000 times. Proportion of significance $(\mathrm{P}<0.05)$ for Fisher's exact $\mathrm{P}$ values are shown.

\begin{tabular}{|c|c|c|c|c|c|}
\hline Sample sizes after complete drift process & Effective population size $\left(\mathrm{N}_{\mathrm{e}}\right)$ & 0.0025 & 0.005 & 0.01 & 0.025 \\
\hline Two clusters $(\mathrm{N}=42$ and $\mathrm{N}=49)$ & $\begin{array}{c}500 \\
1000\end{array}$ & $\begin{array}{l}0.32 \\
0.40\end{array}$ & $\begin{array}{l}0.82 \\
0.82\end{array}$ & $\begin{array}{l}0.99 \\
0.99\end{array}$ & $\begin{array}{l}1.00 \\
1.00\end{array}$ \\
\hline
\end{tabular}

1 and 2 that is, again, independent of geographical area (Paraty or Ubatuba). In relation to the clusters identified by STRUCTURE, the same division of clusters in the DAPC were observed in more than $80 \%$ of the individuals.

In both analyses, two-sample Kolmogorov-Smirnov tests detected no heterogeneity in the frequency distributions of body length and weight for each cluster. The Kolmogorov-Smirnov coefficients for the distributions of the body length and weight from the STRUCTURE clusters were $\mathrm{D}=0.269, \mathrm{P}=0.076$ and $\mathrm{D}=0.275$, $\mathrm{P}=0.065$, respectively. The coefficients for the DAPC clusters were $\mathrm{D}=0.251, \mathrm{P}=0.105$ and $\mathrm{D}=0.245$, $\mathrm{P}=0.132$, respectively. These values indicate that the clusters were not different in terms of body length and weight. The mean length and weight for the 91 individual $C$. undecimalis analysed were $73.10 \pm 13.10 \mathrm{~cm}$ and $3.94 \pm 1.98 \mathrm{~kg}$.

The dispersion plots of the first and second principal components explained $7.4 \%$ of the variance between the geographic and Bayesian divisions, with a clear discrimination of the clusters in the case of Bayesian division (Fig. 3).

The bottleneck results at each locus indicated significant differences between the observed and expected levels of heterozygosity (Table 2). The TPM and SMM analyses showed significant differences for most of the loci in the sign and Wilcoxon tests $(\mathrm{P}<0.05)$. In contrast, no significant values were observed using the IAM ( $\mathrm{P}>0.05$, sign and Wilcoxon tests). To estimate the effective population sizes $\left(\mathrm{N}_{\mathrm{e}}\right)$, we calculated $\mathrm{N}_{\mathrm{e}}$ for the two genetically differentiated groups that were identified using STRUCTURE, Cluster 1 and Cluster 2, which resulted in high and similar values, 736 and 998, respectively. The POWSIM simulation indicated a greater than $99 \%$ probability of our data detecting a degree of population differentiation corresponding to $\mathrm{F}_{\mathrm{ST}}$ values ranging from 0.01 to 0.025 (Table 3).

\section{Epinephelus marginatus}

The eight loci analysed for E. marginatus were highly variable. The number of alleles per locus across all populations ranged from 2 (GAG007) to 11 (GAG011), with a mean of 5.875 and 5.250 for the populations from Paraty and Rio de Janeiro, respectively. The allelic richness showed similar values between the two sites, with an average of $5.34 \pm 0.18$ alleles. Tests results for genotypic linkage disequilibrium led to the rejection of the null hypothesis of independence $(\mathrm{P}<0.01)$ between CAC-3 and GAG010 in samples from Paraty and across all populations. The observed heterozygosity averaged over all loci ranged from 0.444 (Paraty) to 0.503 (Rio de Janeiro), which were lower than the expected values of heterozygosity: 0.605 and 0.655 , respectively. A significant heterozygote deficit was found in several cases. The loci CA-3, GAG023, GAG038, GAG045 and GAG049 did not conform to HWE in any population after a sequential Bonferroni correction. However, the $\mathrm{F}_{\mathrm{ST}} \mathrm{ENA}$ index analysis, which was based on the ENA correction for null alleles, showed low, non-significant $(\mathrm{P}>0.05)$ and quite similar values, $\mathrm{F}_{\mathrm{ST}}=0.00795$ and $\mathrm{F}_{\mathrm{ST}}{ }^{\mathrm{ENA}}=0.00797$, respectively.

The Bayesian analysis (STRUCTURE) indicated only one cluster. Dispersion plots of the first and

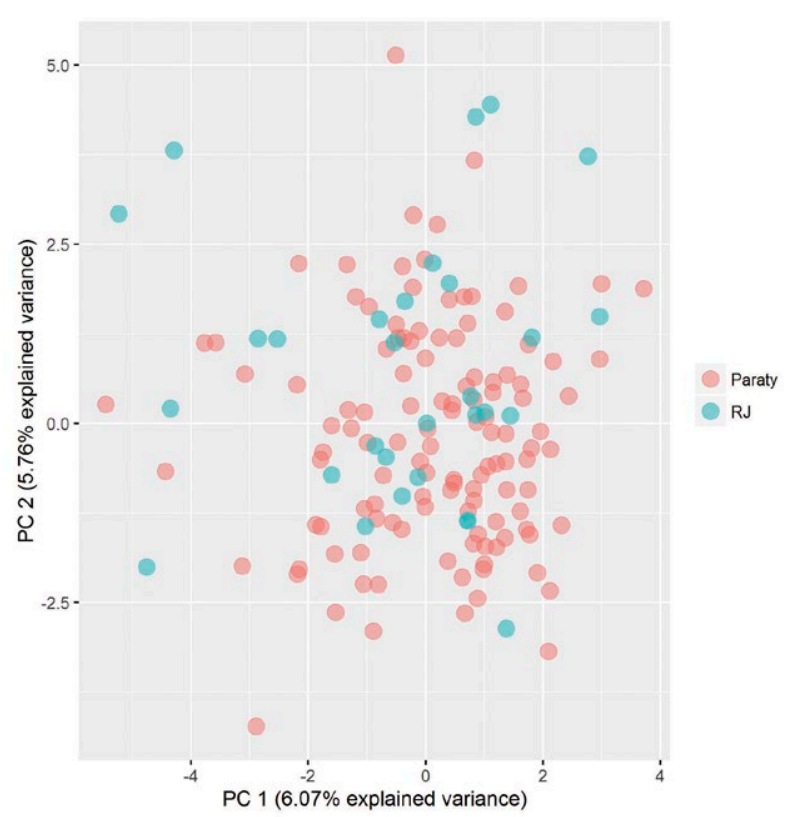

Fig. 4. - Dispersion plot of the first (PC1) and second (PC2) principal components based on the analysis of 152 E. marginatus samples using 8 SSR loci. The red and blue points represent the analysed individuals from Paraty (RJ) and Rio de Janeiro (RJ), respectively. 
Table 4. - Results from the BOTTLENECK tests for eight microsatellite loci studied in the Epinephelus marginatus group (K) identified using STRUCTURE. Sign and Wilcoxon tests for excess heterozygosity: N, number of individuals analysed; Hde, number of loci showing a heterozygosity deficiency; Hex, number of loci showing excess heterozygosity. IAM, Infinite-Allele Model; TPM, Two-Phase Model (90\% $\mathrm{SSM}), \mathrm{SMM}$, Stepwise-Mutation Model, * significant values under the sign/Wilcoxon test $(\mathrm{P} \leq 0.05)$.

\begin{tabular}{lccccccc}
\hline & & IAM & Sign/Wilcoxon tests & TPM \\
Division & $\mathrm{N}$ & Hde/Hex & $\begin{array}{c}\text { Sign/Wilcoxon tests } \\
\mathrm{P}\end{array}$ & $\begin{array}{c}\text { SMM } \\
\text { Hde/Hex }\end{array}$ & $\begin{array}{c}\text { Sign/Wilcoxon tests } \\
\mathrm{P}\end{array}$ \\
\hline $\mathrm{K}$ & 152 & $0 / 8$ & $0.0063 * / 0.0039 *$ & $4 / 4$ & $0.4854 / 0.6406$ & $4 / 4$ & $0.4740 / 0.7422$ \\
\hline
\end{tabular}

second principal components explained $11.8 \%$ of the variance between populations, with all samples from Paraty (red points) and Rio de Janeiro (blue points) in the centre of the component plot, appearing as if they shared the same genetic structure (Fig. 4). These values suggest that within the geographic distribution of E. marginatus from Paraty to Rio de Janeiro, there are no subdivisions of the population. The mean length and weight of the 122 individuals from Paraty were $35.93 \pm 6.41 \mathrm{~cm}$ and $0.90 \pm 0.55 \mathrm{~kg}$. Samples from Rio de Janeiro were not measured. The bottleneck results at each locus according to hypotheses predicting only one $\mathrm{K}$ group exhibited significant differences between the observed and expected levels of diversity (Table 4). Significant excess heterozygosity was observed using the IAM (sign and Wilcoxon tests, $\mathrm{P}<0.05$ ). The effective population size $\left(\mathrm{N}_{\mathrm{e}}\right)$ was calculated for the only genetically differentiated group, $\mathrm{K}=1$, and resulted in 663 individuals between the Paraty (RJ) and Rio de Janeiro (RJ) populations.

\section{DISCUSSION}

The high degree of microsatellite polymorphism enabled the genetic variation of $C$. undecimalis to be studied. Compared with previous reports, we obtained similar average numbers of alleles per locus in the same SSR loci identified by Seyoum et al. (2005) in samples collected from Everglades City, Florida (USA). In a study of $C$. undecimalis (Hernandez-Vidal et al. 2014), the observed rate of polymorphisms was higher, but different collecting sites were selected, including a marine and a freshwater-riverine environment, so the difference may be a result of these different environmental conditions. According to the same authors, high levels of genetic variation are common in marine fish due to the effects of environmental conditions on larval dispersion and to the effects of random mutation fixation processes.

The observed heterozygosity of $C$. undecimalis observed in this study exhibited a range of values that are lower than the previous values described for $C$. undecimalis from the coast of Florida (Seyoum et al. 2005, Hernandez-Vidal et al. 2014). According to DeWoody and Avise (2000), other marine fish have an average heterozygosity of 0.790 . This suggests a lower degree of genetic variability in this fish species in our studied area. Because low genetic diversity can negatively affect the viability of a species (Frankham 2010), more sampling within the Atlantic is necessary to confirm this low diversity.

Significant deviations from HWE due to excess homozygosity were observed at eight of the 15 SSR loci. These values may be attributed to a number of factors, such as population substructure, inbreeding and selection at or near a microsatellite locus, small sample size or the presence of null alleles, the latter being a common artefact of microsatellites. However, the following results were mostly consistent with those obtained when we used the ENA dataset corrected for null alleles (Chapuis and Estoup 2007). Null alleles with a frequency greater than $10 \%$ were observed at the loci Cun01, Cun09, Cun10A, Cun18 and Cun22 in previous studies (Hernandez-Vidal et al. 2014). Previous studies also observed significant departures from HWE expectations for other loci in C. undecimalis (Seyoum et al. 2005).

The analysis of microsatellite loci of $C$. undecimalis from artisanal fishing off the southeastern coast of Brazil showed a different pattern of genetic variation on this geographical scale. Paraty fishing spots are spread out over a relatively large area (Fig. 1), and in the absence of information regarding fishing spots for Ubatuba, a partial overlap between the data obtained from different fishing landings in these two regions may occur. Our results showed no correlation of the two clusters with artisanal fishing spots in Paraty. However, the small but highly significant genetic differentiation detected via several methods (Bayesian method, AMOVA, PCA and DAPC) shows that geographic distribution is not the major structuring factor. The Bayesian clustering method was able to correctly identify the number of sub-populations until the levels of $F_{\mathrm{ST}}$ reached approximately 0.03 (Latch et al. 2006). The level of differentiation for the $C$. undecimalis analysed in our dataset via an AMOVA seemed adequate, i.e. to the detectable limit identified in STRUCTURE. The hierarchical partitioning of genetic variation using an AMOVA also produced a significant result when populations were arranged into main groups (Fitzpatrick 2009), which was observed when we divided the $C$. undecimalis population into two clusters using STRUCTURE. The two clusters observed in the DAPC were also very similar to the STRUCTURE clusters, confirming the hierarchical structure observed. According to Jombart et al. (2010), a DAPC may be useful for analysing a wide variety of organisms independent of their rates of genetic recombination, because this methodology is independent of any effects of population genetics and is therefore free of assumptions relating to the HWE or to linkage disequilibrium.

In a microsatellite DNA analysis of more than 1300 individuals, a substructure was identified for C. undecimalis. Bayesian population analysis using STRUCTURE separated the samples from the Gulf of Mexico off the coast of Florida from the samples from Florida's coastal Atlantic waters (Tringali et al. 2008). Earlier analyses of $C$. undecimalis collected off the coast of Florida based on mitochondrial DNA hap- 
lotypes (Tringali and Bert 1996) were consistent with a hypothesis of restricted gene flow between the Atlantic and Gulf populations. Analyses of mitochondrial DNA haplotypes also indicated genetic differentiation and structuring of Centropomus species off the Brazilian coast (de Oliveira et al. 2014). However, there was no evidence of genetic structure in the stocks within the Florida Gulf or within the Atlantic (Tringali et al. 2008), and no pattern of isolation between C. undecimalis captured in marine (Gulf of Mexico) and freshwater (San Pedro River) environments was observed (Hernandez-Vidal et al. 2014).

Considering that $C$. undecimalis is a euryhaline species with migratory activity between marine, estuarine and fluvial environments throughout its life cycle, different populations may be associated with different migratory movements (Aliaume et al. 2000, Silvano et al. 2006, Perera-Garcia et al. 2013). Previous studies have also shown that larvae are transported inshore, where juveniles colonize estuarine nursery grounds and reside for two to five months (Peterson and Gilmore 1991, Peters et al. 1998). Therefore, it is possible that the substructure observed is due to this migratory process between the sea and coastal rivers, as there are many streams and rivers in the studied area (Fig. 1). The age classes of the individuals can be investigated based on body length and weight, because these factors are correlated with age. The complete understanding of biological characteristics is important because variations in life cycles can exist between fish in estuaries that are geographically close (King and McFarlane 2003, Caselle et al 2011). However, our analyses did not detect heterogeneity in the clusters from STRUCTURE and the DAPC for these traits, indicating that age class was not a determinant for the substructure identified.

An excess of heterozygosity at selectively neutral loci can develop in populations for which the effective size has been reduced. The excess heterozygosity method tests whether the observed heterozygosity is higher than it would be under conditions of mutationdrift equilibrium (Cornuet and Luikart 1996, Piry et al. 1999). The most conservative mutation model is the IAM, because it provides the lowest estimate of expected equilibrium heterozygosity for a given number of alleles observed in a sample. Peery et al. (2012) also demonstrated that the Wilcoxon test is the most reliable test for determining the significance of this parameter. Although tests for excess heterozygosity gave significant results in two of the three models (in the TPM and SMM but not in the IAM) using two different tests (the sign and Wilcoxon tests), our analyses suggest that $C$. undecimalis did not experience a recent bottleneck because the IAM results were not significant. These data could also be confirmed based on the effective population sizes of Cluster 1 and Cluster 2 identified with STRUCTURE. Studies have documented that, in an effective population size of 500 to 5000 individuals, a species is considered to retain its evolutionary potential (Frankham 2010), allowing it to adapt and evolve in response to environmental changes.
The high number of polymorphisms of heterologous SSR loci allowed a study of the genetic diversity of E. marginatus in our target area (Priolli et al. 2014) and in populations in the Mediterranean Sea (De Innocentiis et al. 2001, Schunter et al. 2011). However, the high diversity of alleles may be the result of conservation measures, because some of the Mediterranean sampling areas have been declared marine protected areas in the 1980s (Schunter et al. 2011). On the other hand, null alleles in six of the eight analysed microsatellite loci corroborated the deviation from HWE that was observed in our study (De Innocentiis et al. 2001). Schunter et al. (2011) also found null alleles on other loci studied in E. marginatus from Mediterranean waters.

The low and non-significant global $\mathrm{F}_{\mathrm{ST}}$, Bayesian analysis and PCA values obtained indicate the absence of genetic structuring between E. marginatus populations from the two sampled zones. This may be a consequence of the presence of overlapping spawning areas and/or of strong genetic flow between populations, resulting in a lack of genetic drift and thus limiting the genetic divergence between the populations. $E$. marginatus displays a high degree of reproductive site fidelity, with adults not migrating, which could result in genetic isolation (Hereu et al. 2006). Indeed, fishermen from the Brazilian coast consider this species to be more sedentary and to make only short movements among nearby islands or rocky shores (Silvano et al. 2006). However, the long pelagic larval phase (21 to 30 days) (Spedicato et al. 1998) and the movement of larvae and juveniles in oceanic currents may account for the observed gene flow, spreading genetic variation of this fish species throughout most of the Brazilian coastal waters evaluated in this study. Groupers migrate to spawn, but the distance over which they migrate is variable and poorly understood (Waldie et al. 2016). Connectivity among sub-populations of E. marginatus, through larval dispersion, is seen as a very important factor for demographic and genetic effects, as shown in the Mediterranean Sea, because low connectivity and high self-recruitment can lead to inbreeding depression (Andrello et al. 2013).

Although significant genetic differentiation of $E$. marginatus populations between areas in the Mediterranean Sea and Atlantic Ocean has been found (De Innocentiis et al. 2001, Schunter et al. 2011), previous studies found no systematic relationship with geographic patterns, suggesting that the gene flow is discontinuous and not totally homogeneous. Along the Brazilian coast, evidence of a genetic pattern related to geographic distribution was not observed in Ocyurus chrysurus (Lutjanidae) (Vasconcellos et al. 2008) or Cephalopholis fulva (Epinephelidae) (De Souza et al. 2015). Such evidence was also not found in some studies on Epinephelus itajara (Epinephelidae) (SilvaOliveira et al. 2008, Damasceno et al. 2015). Genetic differentiation in samples from Santa Catarina State in relation to other locations was observed for Epinephelus itajara (Benevides et al 2014).

A bottleneck analysis with the IAM and a Wilcoxon test showed that a bottleneck occurred for $E$. 
marginatus, a species that has been listed as endangered by the IUCN since 1996 . When a bottleneck occurs, the allelic diversity is also reduced more quickly than the heterozygosity, and the effective population size $\left(\mathrm{N}_{\mathrm{e}}\right)$ can reflect inbreeding and the loss of genetic variation (Cornuet and Luikart 1996). Although $\mathrm{N}_{\mathrm{e}}$ calculations were based on temporal data and provide only a rough indication of the present status of the species, E. marginatus was shown to have an effective population size that was lower than that observed for populations in the Mediterranean, West Africa and Senegal (Schunter et al. 2011). Indeed, experienced and older fishermen have mentioned declines in the abundance of this fish species over time along the Brazilian coast (Silvano and Begossi 2012, Lopes et al 2013). Therefore, both genetic data and local ecological knowledge indicate a worrisome decline in the population of this endangered fish.

\section{Concluding remarks}

We present new genetic data on two commercial fish species from artisanal small-scale fisheries off the southeastern Brazilian coast: the common snook and the dusky grouper. The information obtained using microsatellite markers suggests distinct measures for the fisheries' management of these two species along the southeastern Brazilian coast. C. undecimalis populations showed a signal indicating a genetic structure and, therefore, a rejection of the panmixia hypothesis. E. marginatus populations lacked genetic differentiation, which is consistent with a hypothesis predicting a panmictic population. A broader genetic analysis, including the analysis of different genetic markers and more extensive sampling, must be performed in future studies to confirm the lack or existence of genetic structures and determine the limits of their populations. The analysis also indicates that $C$. undecimalis populations have maintained effective population sizes, while the E. marginatus population has decreased. For $C$. undecimalis, its migratory behaviour might explain the inflow of sub-populations within the Paraty estuary. However, the conclusions made in relation to E. marginatus, which is represented by a single population, indicate the existence of mechanisms that maintain gene flow among diverse reef locations. These mechanisms are worth further study because they might be related to ontogenetic phases, such as the larval stage.

\section{ACKNOWLEDGEMENTS}

This work was supported by the São Paulo Research Foundation (FAPESP projects 08/56249-9 and 09/11154-3). R.H.G. Priolli and M.M. Bajay thank the Coordination for the Improvement of Higher Education Personnel (CAPES) and A. Begossi and R.A.M. Silvano thank the National Council for Scientific and Technological Development (CNPq) for scholarships. We also thank N.S. Stabelini, T.B. Andreoli and V. Nora for assistance in the laboratory and in fin collection. We especially thank the fishermen of Paraty, Ubatuba and Rio de Janeiro for their friendly collaboration.

\section{REFERENCES}

Able, K.W. 2005. A re-examination of fish estuarine dependence: Evidence for connectivity between estuarine and ocean habitats. Estuar. Coast. Shelf Sci. 64: 5-17. http://dx.doi.org/10.1016/j.ecss.2005.02.002

Aliaume C., Zerbi A., Joyeux J., et al. 2000. Growth of juvenile Centropomus undecimalis in a tropical island. Environ. Biol. Fishes. 59: 299-308. http://dx.doi.org/10.1023/A:1007662611839

Almeida F.S., Fungaro M.H.P., Sodré L.M.K. 2001. RAPD and isoenzyme analysis of genetic variability in three allied species of catfishes (Siluriformes Pimelodidae) from the Tibagi river, Brazil. J. Zool. 253: 113-120. http://dx.doi.org/10.1017/S0952836901000103

Amorim P., Westmeyer M. 2016. Snapper and Grouper: SFP Fisheries Sustainability Overview 2015. Sustainable Fisheries Partnership Foundation. 18 pp. Available from: http://www.fishsource.com

Anderson A.B., Bonaldo R.M., Barneche D.R., et al. 2014. Recovery of grouper assemblages indicates effectiveness of a marine protected area in Southern Brazil. Mar. Ecol. Prog. Ser. 514: 207-215. http://dx.doi.org/10.3354/meps 11032

Andrade A.B., Machado L.F., Hostim-Silva M., et al. 2003. Reproductive biology of the dusky goruper Epinephelus marginatus (Lowe, 1834). Braz. Arch. Biol. Techn. 46: 373-381. http://dx.doi.org/10.1590/S1516-89132003000300009

Andrello M., Mouillot D., Beuvier J., et al. 2013. Low connectivity between Mediterranean marine protected areas: a biophysical modeling approach for the dusky grouper Epinephelus marginatus. Plos One 8: e68564. http://dx.doi.org/10.1371/journal.pone.0068564

Begossi A., Salivonchyk S.V., Hanazaki N., et al. 2012a. Fishers (Paraty, RJ) and fish manipulation time: a variable associated to the choice for consumption and sale. Braz. J. Biol. 72: 973-975. http://dx.doi.org/10.1590/S1519-69842012000500030

Begossi A., Salyvonchyk S., Nora V., et al. 2012b. The paraty artisanal fishery (southeastern Brazilian coast): ethnoecology and management of a social-ecological system (SES). J. Ethnobiol. Ethnomed. 8: 22-40. http://dx.doi.org/10.1186/1746-4269-8-22

Benevides E.A., Vallinoto M.N.S., Fetter Filho A.F.H., et al. 2014. When physical oceanography meets population genetics: The case study of the genetic/evolutionary discontinuity in the endangered goliath grouper (Epinephelus itajara; Perciformes: Epinephelidae) with comments on the conservation of the species. Biochem. Syst. Ecol. 56: 255-266. http://dx doi org/10.1016/i.bse.2014.06.004

Bouchereau J.L., Body P., Chauvet C. 1999. Growth of the dusky grouper Epinephelus marginatus (Linnnaeus, 1758) (Teleostei, Serranidae), in the natural marine reserve of Lavezzi Islands, Corsica, France. Sci. Mar. 63: 71-77. http://dx.doi.org/10.3989/scimar.1999.63n171

Brookfield J.F.Y. 1996. A simple new method for estimating null allele frequency from heterozygote deficiency. Mol. Ecol. 5: 453-455.

http://dx.doi.org/10.1111/j.1365-294X.1996.tb00336.x

Caselle J.E., Hamilton S.L., Schroeder D.M., et al. 2011 Geographic variation in density, demography, and life history traits of a harvested, sex-changing, temperate reef fish. Can. J. Fish. Aquat. Sci. 68: 288-303. http://dx.doi.org/10.1139/F10-140

Chapman R.W., Sedberry G.R., Koenig C.C., et al. 1999. Stock identification of gag, Mycteroperca microlepis, along the southeast coast of the United States. Mar. Biotechnol. 1: 137-146. http://dx.doi.org/10.1007/PL00011761

Chapuis M.P., Estoup A. 2007. Microsatellite null alleles and estimation of population differentiation. Mol. Biol. Evol. 24: 621-631. http://dx.doi.org/10.1093/molbev/ms1191

Cornuet J.M., Luikart G. 1996. Description and power analysis of two tests for detecting recent population bottlenecks from allele frequency data. Genetics 144: 2001-2014.

Damasceno J.S., Siccha-Ramirez R., Morales M.J.A., et al. 2015. Mitochondrial DNA evidences reflect an incipient population structure in Atlantic goliath grouper (Epinephelus itajara, Epinephelidae) in Brazil. Sci. Mar. 79: 419-429. http://dx.doi.org/10.3989/scimar.04203.20A

De Innocentiis S., Sola L., Cataudella S., et al. 2001. Allozyme and 
microsatellite loci provide discordant estimates of population differentiation in the endangered dusky grouper (Epinephelus marginatus) within the Mediterranean Sea. Mol. Ecol. 10: 2163-2175.

http//dx doi.org/10.1046/j.1365-294X.2001.01371.x

De Oliveira J.N., Gomes G., do Rego P.S., et al. 2014. Molecular data indicate the presence of a novel species of Centropomus (Centropomidae - Perciformes) in the Western Atlantic. Mol. Phylogenet. Evol. 77: 275-280. http://dx.doi.org/10.1016/j.ympev.2014.04.019

De Souza A.S., Dias E.A. Jr., Galetti P.M. Jr., et al. 2015. Widerange genetic connectivity of Coney, Cephalopholis fulva (Epinephelidae), through oceanic islands and continental Brazilian coast. An. Acad. Bras. Cienc. 87: 121-136. http://dx.doi.org/10.1590/0001-3765201520130411

Dempster A.P., Laird N.M., Rubin D.B. 1977. Maximum likelihood from incomplete data via em algorithm. J. R. Stat. Soc. Ser. B. Methodol. 39: 1-38.

DeWoody J.A., Avise J.C. 2000. Microsatellite variation in marine, freshwater and anadromous fishes compared with other animals. J. Fish. Biol. 56: 461-473. http://dx.doi.org/10.1111/j.1095-8649.2000.tb00748.x

Earl D.A., VonHoldt B.M. 2012. Structure Harvester: a website and program for visualizing Structure output and implementing the Evanno method. Conserv. Genet. Resour. 4: 359-361. http://dx.doi.org/10.1007/s12686-011-9548-7

Evanno G., Regnaut S., Goudet J. 2005. Detecting the number of clusters of individuals using the software Structure: a simulation study. Mol. Ecol. 14: 2611-2620. http://dx.doi.org/10.1111/j.1365-294X.2005.02553.x

Excoffier L., Laval G., Schneider S. 2005. Arlequin (version 3.0): An integrated software package for population genetics data analysis. Evol. Bioinform. 1: 47-50.

Fitzpatrick B.M. 2009. Power and sample size for nested analysis of molecular variance. Mol. Ecol. 18: 3961-3966. http://dx.doi.org/10.1111/j.1365-294X.2009.04314.x

Frankham R. 2010. Challenges and opportunities of genetic approaches to biological conservation. Biol. Conserv. 143: 1919-1927. http://dx.doi.org/10.1016/j.biocon.2010.05.011

Ginestet C. 2011. GGPLOT2: Elegant Graphics for Data Analysis. J. R. Stat. Soc. Ser. A Stat. Soc. 174: 245-246. http://dx.doi.org/10.1111/j.1467-985X.2010.00676 9.x

Goudet J. 1995. FSTAT (Version 1.2): A computer program to calculate F-statistics. J. Hered. 86: 485-486.

Hereu B., Diaz D., Pasqual J., et al. 2006. Temporal patterns of spawning of the dusky grouper Epinephelus marginatus in relation to environmental factors. Mar. Ecol. Prog. Ser. 325: 187-194. http://dx.doi.org/10.3354/meps325187

Hernandez-Vidal U., Lesher-Gordillo J., Contreras-Sanchez W.M., et al. 2014. Genetic variability of the Common Snook Centropomus undecimalis (Perciformes: Centropomidae) in connected marine and riverine environments. Rev. Biol. Trop. 62: 627-636.

Hubisz M.J., Falush D., Stephens M., et al. 2009. Inferring weak population structure with the assistance of sample group information. Mol. Ecol. Resour. 9: 1322-1332. http://dx.doi.org/10.1111/j.1755-0998.2009.02591.x

Jakobsson M., Rosenberg N.A. 2007. Clumpp: a cluster matching and permutation program for dealing with label switching and multimodality in analysis of population structure. Bioinformatics 23: 1801-1806. http://dx.doi.org/10.1093/bioinformatics/btm233

Jombart T. 2008. Adegenet: a R package for the multivariate analysis of genetic markers. Bioinformatics 24: 1403-1405. http://dx.doi.org/10.1093/bioinformatics/btn129

Jombart T., Devillard S., Balloux F. 2010. Discriminant analysis of principal components: a new method for the analysis of genetically structured populations. BMC Genet. 2010, 11: 94. http://dx.doi.org/10.1186/1471-2156-11-94

King J.R., McFarlane G.A. 2003. Marine fish life history strategies: applications to fishery management. Fisheries Manag. Ecol. 10: 249-264. http://dx.doi.org/10.1046/j.1365-2400.2003.00359.x

Latch E.K, Dharmarajan G., Glaubitz J.C., et al. 2006. Relative performance of Bayesian clustering software for inferring population substructure and individual assignment at low levels of population differentiation. Conserv. Genet. 7: 295-302. http://dx.doi.org/10.1007/s10592-005-9098-1

Lopes P.F.M, Rosa E.M., Salyvonchyk S., et al. 2013. Suggestions for fixing top-down coastal fisheries management through participatory approaches. Mar. Policy 40: 100-110. http://dx.doi.org/10.1016/j.marpol.2012.12.033

McClanahan T.R., Marnane M.J., Cinner J.E., et al. 2006. A comparison of marine protected areas and alternative approaches to coral-reef management. Curr. Biol. 16: 1408-1413. http://dx.doi.org/10.1016/j.cub.2006.05.062

Mumby P.J., Harborne A.R., Brumbaugh D.R. 2011. Grouper as a Natural Biocontrol of Invasive Lionfish. PLoS One 6: e21510. http://dx.doi.org/10.1371/journal.pone.0021510

Paradis E., Claude J., Strimmer K. 2004. APE: Analyses of Phylogenetics and Evolution in R language. Bioinformatics 20: 289-290. http://dx.doi.org/10.1093/bioinformatics/btg412

Peery M.Z., Kirby R., Reid B.N., et al. 2012. Reliability of genetic bottleneck tests for detecting recent population declines. Mol. Ecol. 21: 3403-3418. http://dx.doi.org/10.1111/j.1365-294X.2012.05635.x

Perera M.A., Mendoza M., Contreras W.M., et al. 2011. Reproductive biology of common snook Centropomus undecimalis (Perciformes: Centropomidae) in two tropical habitats. Rev. Biol. Trop. 59: 669-681.

Perera-Garcia M.A., Mendoza-Carranza M., Contreras-Sanchez W., et al. 2013. Comparative age and growth of common snook Centropomus undecimalis (Pisces: Centropomidae) from coastal and riverine areas in Southern Mexico. Rev. Biol. Trop. 61: 807-819. http://dx.doi.org/10.15517/rbt.v61i2.11224

Peters K.M., Matherson R.E., Taylor R.G. 1998. Reproduction and early hsitory of common snook, Centropomus undecimalis (Bloch), in Florida. Bull. Mar. Sci. 62: 509-529.

Peterson M.S., Gilmore R.G. 1991. Eco-physiology of juvenile snook Centropomus undecimalis (Bloch) - Life-history implications. Bull. Mar. Sci. 48: 46-57.

Pinnegar J.K., Engelhard G.H. 2008. The 'shifting baseline' phenomenon: a global perspective. Rev. Fish. Biol. Fish. 18: 1-16. http://dx.doi.org/10.1007/s11160-007-9058-6

Piry S., Luikart G., Cornuet J.M. 1999. Bottleneck: A computer program for detecting recent reductions in the effective population size using allele frequency data. J. Heredity 90: 502-503. http://dx.doi.org/10.1093/jhered/90.4.502

Priolli R.H.G., Stabelini N.S., Bajay M.M. 2014. Diversidade genética de uma espécie em perigo de extinção: a garoupa Epinephelus marginatus. In Begossi A., Lopes P.F.M. (eds), Comunidades pesqueiras de Paraty sugestões para manejo. RiMa Editora, São Carlos, pp. 27-40.

Pritchard J.K., Stephens M., Donnelly P. 2000. Inference of population structure using multilocus genotype data. Genetics 155 : 945-959.

R Development Core Team. 2015. R: A language and environment for statistical computing. The R Foundation for Statistical Computing. Vienna, Austria. Available online at http://www.R-project.org/

Ramirez M.A., Patricia-Acevedo J., Planas S., et al. 2006. New microsatellite resources for groupers (Serranidae). Mol. Ecol. Notes 6: 813-817. http://dx.doi.org/10.1111/j.1471-8286.2006.01354.x

Raymond M., Rousset F. 1995. GENEPOP (version-1.2) - population-genetics software for exact tests and ecumenicism. J. Heredity 86: 248-249.

Rice W.R. 1989. Analyzing tables of statistical tests. Evolution 43: 223-225. http://dx.doi.org/10.2307/2409177

Rivera M.A.J., Graham G.C., Roderick G.K. 2003. Isolation and characterization of nine microsatellite loci from the Hawaiian grouper Epinephelus quernus (Serranidae) for population genetic analyses. Mar. Biotechnol. 5: 126-129. http://dx.doi.org/10.1007/s10126-002-0093-y

Ryman N., Palm S. 2006. POWSIM: a computer program for assessing statistical power when testing for genetic differentiation. Mol. Ecol Notes 6: 600-602. http://dx.doi.org/10.1111/j.1471-8286.2006.01378.x

Ryman N, Palm S, André C., et al. 2006. Power for detecting genetic divergence: differences between statistical methods and marker loci. Mol. Ecol. 15: 2031-2045. http://dx.doi.org/10.1111/j.1365-294X.2006.02839.x

Schunter C., Carreras-Carbonell J., Planes S., et al. 2011. Genetic connectivity patterns in an endangered species: The dusky grouper (Epinephelus marginatus). J. Exp. Mar. Biol. Ecol. 401: 126-133. 
http://dx.doi.org/10.1016/j.jembe.2011.01.021

Seyoum S., Tringali M.D., Sullivan J.G. 2005. Isolation and characterization of 27 polymorphic microsatellite loci for the common snook, Centropomus undecimalis. Mol. Ecol. Notes 5: 924-927. http://dx.doi.org/10.1111/j.1471-8286.2005.01118.x

Shiozawa D.K., Kudo J., Evans R.P., et al. 1992. DNA extraction from preserved trout tissues. Gt. Basin Nat. 52: 29-34.

Silva-Oliveira G.C., do Rego P.S., Schneider H., et al. 2008. Genetic characterisation of populations of the critically endangered Goliath grouper (Epinephelus itajara, Serranidae) from the Northern Brazilian coast through analyses of mtDNA. Genet. Mol. Biol. 31: 988-994. http://dx.doi.org/10.1590/S1415-47572008005000013

Silvano R.A.M., Begossi A. 2012. Fishermen's local ecological knowledge on Southeastern Brazilian coastal fishes: contributions to research, conservation, and management. Neotrop. Ichthyol. 10: 133-147. http://dx.doi.org/10.1590/S1679-62252012000100013

Silvano R.A.M., MacCord P.F.L., Lima R.V., et al. 2006. When does this fish spawn? Fishermen's local knowledge of migration and reproduction of Brazilian coastal fishes. Environ. Biol. Fish. 76: 371-386 http://dx.doi.org/10.1007/s10641-006-9043-2

Snedecor G.W., Cochran W.G. 1989. Statistical Methods, 8th ed. Iowa State University Press, Ames.

Spedicato M.T., Contegiacomo M., Carbonara P., et al. 1998. Artificial reproduction of Epinephelus marginatus aimed at the development of restocking techniques. Biol. Mar. Mediterr. 5: 1248-1257.

Taylor R.G., Whittington J.A., Grier H.J., et al. 2000. Age, growth, maturation, and protandric sex reversal in common snook, Centropomus undecimalis, from the east and west coasts of South Florida. Fish. Bull. 98: 612-624.

Tringali M.D., Bert T.M. 1996. The genetic stock structure of common snook (Centropomus undecimalis). Can. J. Fish Aquat. Sci. 53: $974-984$ http://dx.doi.org/10.1139/f96-027

Tringali M.D., Seyoum S., Wallace E.M., et al. 2008. Limits to the use of contemporary genetic analyses in delineating biological populations for restocking and stock enhancement. Rev. Fish. Sci. 16: 111-116. http://dx.doi.org/10.1080/10641260701686887

Van Oosterhout C., Hutchinson W.F., Wills D.P.M., et al. 2004. MICRO-CHECKER: software for identifying and correcting genotyping errors in microsatellite data. Mol. Ecol. Notes 4: $535-538$. http://dx.doi.org/10.1111/j.1471-8286.2004.00684.x

Vasconcellos A.V., Vianna P., Paiva P.C., et al. 2008. Genetic and morphometric differences between yellowtail snapper (Ocyurus chrysurus, Lutjanidae) populations of the tropical West Atlantic. Genet. Mol. Biol. 31: 308-316. http://dx.doi.org/10.1590/S1415-47572008000200026

Waldie P.A., Almany, G.R., Sinclair-Taylor T.H., et al. 2016. Restricted grouper reproductive migrations support communitybased management. R. Soc. Open Sci. 3: 150694 http://dx.doi.org/10.1098/rsos.150694

Waples R.S., Do C. 2008. LDNE: a program for estimating effective population size from data on linkage disequilibrium. Mol. Ecol. Resour. 8: 753-756.

http://dx.doi.org/10.1111/j.1755-0998.2007.02061.x 